\title{
The Actantial and Functional Structure Analysis of Fairytale Beauty and The Beast
}

\author{
Dwi Nur Cahyani Sri K. \\ Universitas Negeri Surabaya \\ Surabaya, Indonesia \\ dwikusumaningtyas@unesa.ac.id
}

\begin{abstract}
This study is aimed to find how structural narrative which is in Beauty and The Beast fairytale by using structuralism narratology A.J. Greimas. The purpose of this study is to obtain, examine, understand and describe the actantial and functional structure of Beauty and The Beast. The result of the study concludes that the analysis of main actantial scheme and functional structure is the Beast looking for his true love to break the curse. The desire and wish of the characters which are the activator to looking for his true love.
\end{abstract}

Keywords-actantial, functional, structuralism, narrative structuralism, Beauty and The Beast.

\section{INTRODUCTION}

Fairytale is one of literary works. Fairytale is a short story and usually written for children. It tells about magical creatures, idealized or extremely happy [1]. The story of fairytale is rare in the real world because, the characters of fairytale are animal, giant, dwarf, trolls, whiches and similar to them.

Fairytale in the literary sense is easy to find. They belong to no one and have been adapted and retold countless times. Fairytale is an oral story and it is based on an artistic fiction. It had been orally created during centuries and transferred from generation to generation [2]. Fairytales do not need to be written down to be legitimate. Beauty and The Beast is one of fairytale which tells about the prince who is cursed to be a Beast by a witch.

Based on those stories, this study chooses Beauty and The Beast as the object of the study. This study focuses on the structure of a story by using structural narrative which is developed by A.J Greimas. A.J Greimas describes actants and functional scheme and also the relationship to each other in the story[2].

Within this framework, this study is conducted to answer two research questions as follows: 1 . What are the actant and functional scheme in Beauty and The Beast, and 2. How is the relation between actants and functional scheme in Beauty and The Beast.

To answer the two research questions above, this study used structural narrative theory to analyze fairytale Beauty and The Beast which are seen from actantial and functional scheme. This structuralism model is used because the structural narrative of Greimas is considered to have an advantage in presenting the detail of character life from the beginning to the ending of the story. In addition, this structuralism model has clearly been able to demonstrate and differentiate between protagonist and antagonist character[3,p.146].

Piaget [4, p.4] "Structure consists of elements which close in a relationship and systematic to form the unity and the wholeness of literary work". There are three ideas about the elements contained in the structure. The first is the wholeness, it means that all elements which build a text determine its self significant and determine all significant in the intrinsic norm. Also, all elements adapt themselves to the other element.

Piaget [4, p.4] "Structure consists of elements which close in relationship and systematic to form the unity and the wholeness of literary work". There are three ideas about the element that contained in the structure. The first is the wholeness, it means that all elements which build a text determine its self significant and determine all significant in intrinsic norm. Also all elements adapt themselves to the other element.

The theories are summarized into two point as follows :

\section{1) Actantial}

Actantial structure used to describe the role of the character situasion, feelings, a thing from the stories which based on binary opposition such as : subject object, sender - receiver, helper - opponent. There is structure of actantial.

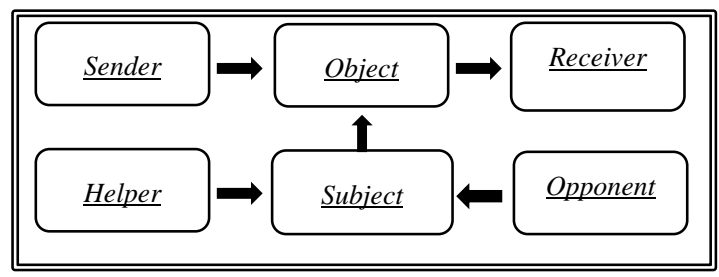

Fig. 1: Actantial Scheme

As indicated in Figure 1, the element of the actantial can be explain based on their function. A sender wishes to transmit or communicate an object to receiver. Sender is an actant who or which has desire and is activator of the story[10]. The sender gives a subject the mandate to perform or get sender's 
request. Receiver is the character who undertakes the quest that is asked by sender. The opponent is a figure or force that tries to precent the subject from carrying out the commision. Helper is an actant who or which help subject [11].

\section{2) Functional}

Besides showing actantial structure, Greimas find functional structural. The function of a functional model used to explain the role of the subject in order to carry out the assignment from the sender which is contained in the actant[5]. The functional model is closely related to the actantial model because the relations between one actant and the others are determined by their functions [6]. Fossion who is cited by Hacette in his book of lectures Nouvelles said that "all stories despite in different forms show that there is the same configuration on the types of actant which is defined by relation and function played in stories." [5, p.4] The function of functional scheme is describing more detail the role of the subject to get an object affected by the sender based on the plot. Functional scheme divide into 3 stages; initial situation, the transformation stage and the final situation [9].

A.J Greimas developed structuralism into narrative structuralism. Narrative structures considered by Greimas in order to explain the gradual evolution of sequences and the formation of the story to compare the sensible/stative model[6].

Greimas tells about the relationship between characters (actants) from the stories. Based on that statement, the relationship among the characters needs to be analyzed to find actants and functional of the characters.

\section{METHODS}

To analysis, this literary work, the method of the study is a qualitative-descriptive method. Qualitative data in this study refers to text from the fairytale Beauty and The Beast. Descriptive studies are described in more detail about the correlation between actants and functional models.

In this study, the data collected are analyzed by using the structural theory of A.J Greimas. To analyzing the data, firstly identifying actant scheme and functional models in Beauty and The Beast, find the main actant and functional and identifying the relationship between them in the story.

\section{RESULTS AND DISCUSSION}

This study focused on 3 characters who have important role in Beauty and The Beast. There are Beauty, The Merchant (Beauty's father) and The Beast (Prince).

In this study, Beauty and The Beast has 8 actant and 8 functional schemes that actant is described more detail to find the role of character.

A. The actant structure as follows :

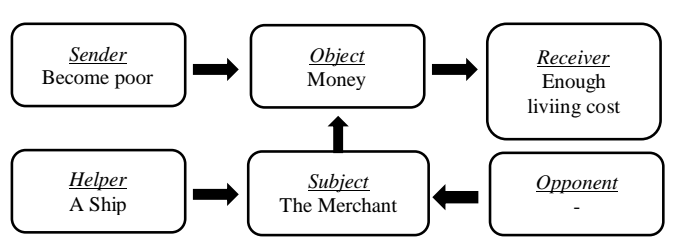

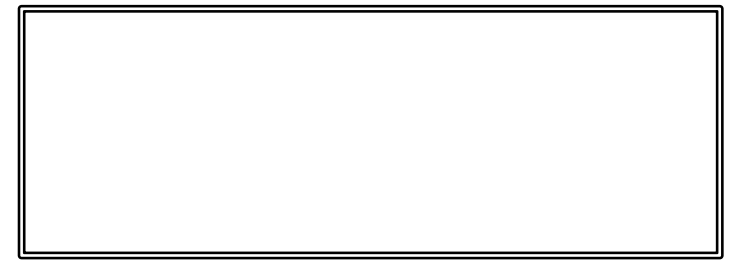

Fig. 2: Actantial scheme 1

In Figure 2, the Merchant has a role as a subject who desires money (object). The Merchant's life was changing to become a poor family so he needs money to sufficient his family's needs (receiver). All at once the Merchant lost his whole fortune, excepting a small country-house at a great distance from town, and told his children, with tears in his eyes, they most go there and work for their living [12, P.1]. The sender from this actant is the change of Merchant's family life. It becomes an activator of a subject to get an object in order to a receiver. There is a ship as a helper to help the Merchant desire.

A father should be responsible for his daughter. He is like a superhero who is without being asked will make efforts to protect and support his child. Although his main responsibility is supporting his family, a father should present the fundamental qualities of leadership, responsibility, and accountability, as well as the capabilities of planning, disciplining and loving. Fathering is a full-time job, it is not a big difference with mother.

\section{Functional structure}

Initial situation: The story begins with The Merchant's life who had six children. Being a man of sense, he spared no cost for their education but gave them all kinds of masters.

Qualifying test of transformation: The Merchant's family was happy because they were rich. The two eldest had a great deal of pride and went out every day upon parties of pleasure, balls, plays, concerts, etc. The youngest one, Beauty is different from another child because she spent the greatest part of her time in reading books. Main test of transformation: The Merchant lost his whole fortune. They moved to a small country-house at a great distance from town and must work for their living. Glorifying test of transformation: He and his child must work to make living. Two eldest one won't leave the town and did nothing, meanwhile Beauty at four in the morning, and made haste to clean the house and prepared breakfast for her family. After she had done her work, she read, played on the harpsichord, or else sung whilst she spun.

Final situation The Merchant received a letter, with an account that a vessel, on board of which he had effects, was safely arrived. The Merchant wants to join the ship. Before leaving, he asks his children if they wish for him to bring any gifts back for them. His oldest daughters ask for clothing, jewels, and the finest dresses possible as they think his wealth has returned. 


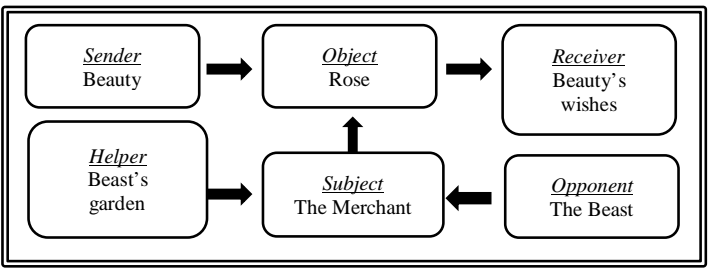

Fig. 3: Actantial scheme 2

As illustrated in Figure2, Beauty as a sender is in actant 2. "Since you are so kind as to think of me, (answered she,) be so kind as to bring me a rose, for as none grow hereabouts, they are a kind of rarity." [12, P.2]From that quotation, Beauty wants a rose from her father. Bring me a rose shows that the object of this actant and Beauty's wishes as a sender. A rose as an object must be obtained by subject in order to sender, Beauty.

\section{Functional Structure}

Initial situation : The Merchant loses his way to go home but he lost himself in a larger forest. It rained and snowed terribly, besides, the wind was so high. He begins to apprehend being either starved to death with cold and hunger.

Qualifying test of transformation: The Merchant returned God thanks for this happy discovery, and hasted to the palace, but was greatly surprised at not meeting with anyone in the outcourts. He was entering into a large hall, he found a good fire, and a table full of food, but no one. $\mathrm{He}$ waited a considerable time, till it struck eleven, and still, nobody came: at least he was so hungry that he could stay no longer, but took a chicken and ate it in two mouthfuls, trembling all the while. Main test of transformation: The Merchant woke up the next morning and he was astonished to see a good suit of clothes in the room of his own. He looked through a window, but instead of snow, he saw the most delightful arbors, interwoven with the most beautiful flowers that ever were beheld. He remembered Beauty's request to him and gathered a branch on which were several roses. Glorifying test of transformation: The Beast, owner of the palace, was angry because the Merchant took a branch of roses without permission. The roses which the Beast value beyond anything in the universe were stolen by the Merchant, so he must pay it with his life.

Final situation: The Merchant fell on his knees, and he lifted up both his hands. He asked for forgiveness from the Beast (see Figure 4).

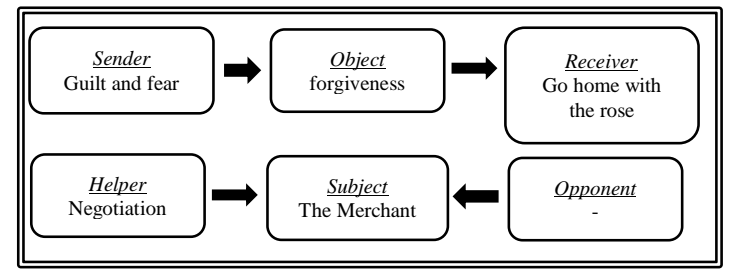

Fig. 4: Actantial scheme 3

The Merchant as a subject feels guilty and fear of The Beast's anger (sender). The Merchant asks for forgiveness because he wants to go home with that rose for her daughter. Because the Merchant wants to make his daughter happy, he try to fulfill his daughter wants. Based on this actant, we can see that there is a father's struggle to his family. He will do anything just for his family. "My Lord (said he,) I beseech you to forgive me, indeed I had no intention to offend in gathering a rose for one of my daughters,......." [12, P.4] He works, he remember what his daughter wants, he tries to negotiate to the Beast and asks forgiveness because he wants to come back to his family.

\section{Functional Structure}

Initial situasion : The Merchant asks for forgiveness from the Beast. "My Lord (said he,) I beseech you to forgive me, indeed I had no intention to offend in gathering a rose for one of my daughters, who desired me to bring her one."

Qualifying test of transformation: The Beast will forgive The Merchant with one condition; The Merchant should bring her daughter to him within three months. Main test of transformation: The Merchant agree and had no mind to sacrifice his daughters to the ugly monster, but he thought, in obtaining this respite, he should have the satisfaction of seeing his daughter once more. Glorifying test of transformation: The Beast told him that he can go back to the room where the Merchant lay and permit him to take everything that the Merchant likes and will send it to his house.

Final situation; The horse, of The Merchant own accord, took one of the roads of the forest; and in a few hours, the good man was at home.

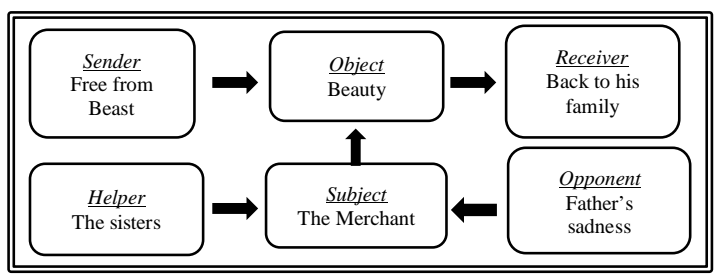

Fig. 5: Actantial scheme 4

Figure 5 shows that in actant 4 we can see that there is a father's struggle to his family. "...I had no intention to offend in gathering a rose for one of my daughters, who desired me to bring her one." [12 ,P.4] He will do anything just for his family. He works, he remembers what Beauty wants but makes the Beast angry. he asks forgiveness to the Beast because he wants to come back to his family

\section{Functional Structure}

Initial situation: The Merchant back to his home and his children came around him. Instead of receiving their embraces with pleasure, he looked on them and burst into tears.

Qualifying test of transformation: He gives the roses to Beauty and told them what happen with him on the way back home. Main test of transformation: Beauty delivers herself into the Beast. Because she made this trouble to her father. Glorifying test of 
transformation: Her brothers don't permit her to go to the Beast. They will fight for her and his father. But, the father doesn't agree with that idea.

Final situation: Her father so afflicted at the thoughts of losing his daughter, that he had quite forgotten about the gold that he brings before.

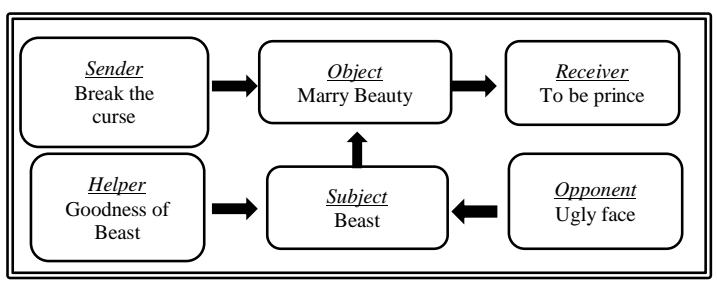

Fig. 6: Actantial scheme 5

Figure 6 illustrates that the Beast as a subject in actant 5. The Beast wants to marry Beauty (object), but the Beast's wishes are blocked by his terrible face (opponent). The Beast wants to marry Beauty is the role of the activator of the story. "Beauty, will you be my wife?" [12,P.10] This quotation shows how serious the Beast wants Beauty to become his lover although he has another goal that he wants to break the curse that made his face terrible. The curse can be removed if the Beast finds his true love. He hopes that Beauty becomes his true love. The Beast looking for his true love because true love doesn't look at his appearance. The Beast realized that he had a terrible face, it makes many people do not want him to be their lover or their true love and feel fear of him.

\section{Functional Structure}

Initial situation : Beauty and her father are going to Beast's palace to fulfill his promise. The Beast let the Merchant leave the palace and make Beauty as a prisoner.

Qualifying test of transformation: The Beast tries to approach Beauty to help him break the curse. The Beast invited Beauty to take dinner together every night. Main test of transformation: Three months passed, the Beast purpose Beauty to marry him. Glorifying test of transformation: Beauty always rejected the Beast's proposal.

Final situation: Beast asks her to never leave him even though he has a terrible face for his lifetime.

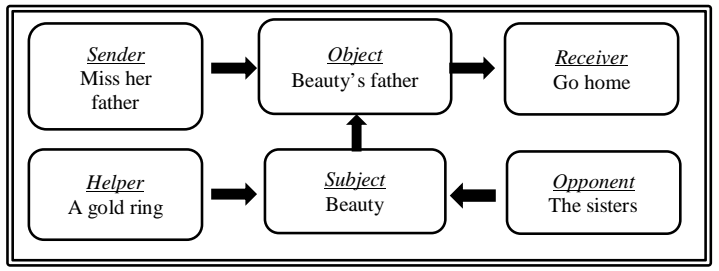

Fig. 7: Actantial scheme 6

In Figure 7, Beauty has a role as a subject. Beauty has the desire to meet her father (object) because she misses him so much. After several months she was detained in the Beast's palace, she thinks about her father. Her feel which missing her father become an activator in this scheme. The Beast gives Beauty a gold ring to help her to go back to her father, but with one condition. She must promise to return to Beast's palace. Bella's love for her father never ends because she felt her father's love for her is never end too.

\section{Functional Structure}

Initial situation : Beauty had seen in her glass, that her father had pined himself sick for the loss of her and she wants to see him again.

Qualifying test of transformation: The Beast asks Beauty to do not to leave him and will stay in the palace with the Beast even she doesn't want to marry him. Main test of transformation: Beauty agrees and promises not to leave him and will stay in the palace to accompany him. But, she has one desire to see her father first before she throws her self as a servant to the Beast. Glorifying test of transformation: The Beast feel so disappointed because Beauty will leave him and go back to her father. He will die with his loneliness and grief.

Final Situation: Beauty promise, she will return to the palace a week. She just wants to stay with her father because he is alone. Her sister and brother are married. The Beast gives a ring to Beauty. That ring will send her to her father's house if it lays in beside her.

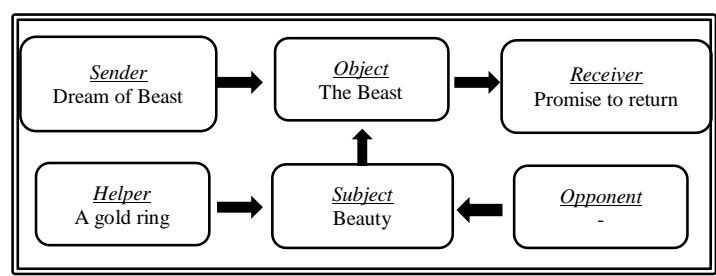

Fig. 8: Actantial scheme 7

As indicated in Figure 8, Beauty dreams about the Beast have a role as a sender of activator this actant. It makes Beauty remembers and wants to meet the Beast (object). She wants to fulfill her promise, to return into Beast's Palace because she feels guilty to forget the Beast's kind and besides that, the Beast believes her that she will fulfill her promise.

\section{Functional Structure}

Initial situation : In the next morning, Beauty woke up in her father's house. Her father feels so happy to see her again but on the other hand Beauty's sisters sickened with envy, when they saw her dressed like a princess, and more beautiful than ever; nor could all her obliging affectionate behavior to stifle their jealousy, which was ready to burst when she told them how happy she was.

Qualifying test of transformation: Beauty's sister was envious and wanted to hold Beauty for not to keep her promise so the Beast will angry with her. The tenth night she spent at her father's, she dreamed she was in the palace garden, and that she saw the Beast extended on the grass-plot, who seemed just expiring, and, in a dying voice, reproached her with her ingratitude. Main test of transformation: Beauty cried and she thinks that she is very evil for the Beast. The Beast very kind and have a good 
attitude to her even though he has a terrible face but he cares and loves Beauty. Beauty thinks that his terrible face is not that wrong, and why she refused his proposal to marry her. Glorifying of transformation: She puts her ring on the table and then laid down again. She waked the next morning, she was overjoyed to find herself in the Beast's palace.

Final Situation: She keeps her promise to return the Beast's palace

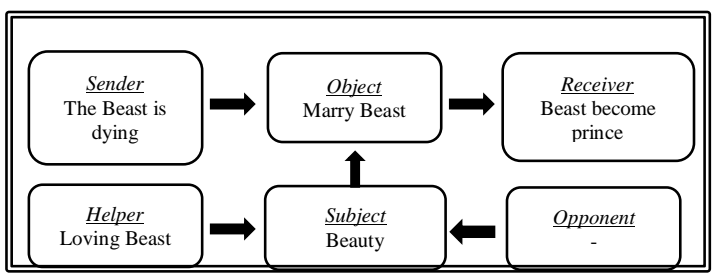

Fig. 9: Actantial scheme 8

In Actant 8 (see Figure 9), the dying Beast (sender) become a reason or mover of Beauty to meet him because Beauty dreamed about the dying Beast Likewise, the desire of Beauty for the Beast not to die, it becomes mover of Beauty to marry him (object).

Beauty does not realize it, if she has been interested with the Beast. Because, the Beast always be kind to Beauty, it makes Beauty does not afraid and disgusted with his terrible face.

Love is something difficult to describe. Love will not have any restrictions on appearance, material and habit. In this scheme, finally, Beauty realize that she loves the Beast (helper) because of the Beast's kindness and good attitude. Beauty put aside that terrible face of the Beast, and realized that she really didn't want to lose the Beast. Based on this, Beauty wants to marry the Beast on the other hand the Beast finds true love in Beauty.

\section{Functional Structure}

Initial situation:mBeauty returns to the Beast's palace. She is looking for the Beast but she does not find him. She is feared that she had been the cause of his death.

Qualifying test of transformation: She ran crying and wringing her hands all about the palace, like one in despair. She remembered her dream to found where the Beast was dying. Main test of transformation: She finds the Beast stretched, and as she imagined, dead. She threw herself upon him without any dread and finding his heartbeat. The Beast is disappointed because he thinks that she forgets her promise to return, and he resolved to starve himself. Glorifying of transformation: Beauty feels sorry to the Beast after leaving him alone, and she does not want to lose the Beast. Beauty said that she loved the Beast ad wanted to make the Beast her husband.

Final Situation: The Beast had disappeared and she saw one of the loveliest princes that eye ever beheld. Beauty surprise and give the charming Prince her hand to rise and they went together into the palace. After all, Beauty overjoys to find her father and his whole family in the palace.

\section{B. The Relationship Between Actant and Functional Structures}

From the analysis above, there are 8 actant and functional structures. The main framework from the fairytale Beauty and The Beast, among them, is actant scheme 5. In actant and functional scheme 5, there is the key to the story. The Beast's deepest wishes are marrying Beauty but blocked by his terrible face. There are two opposing sites between his desire and his real condition. When the Beast proposes Beauty, he knows what Beauty will say and respond but he still determined to say it. There is no doubt when the Beast proposes Beauty as if he was sure that Beauty is different from anyone else because Beauty has no choice to accept his propose or he will angry with Beauty's respond. But, Beauty is smart enough, she does not answer the Beast's proposal directly. "Beast, you make me very uneasy, I wish I could consent to marry you, but I am too sincere to make you believe that will ever happen: I shall always esteem you as a friend; endeavor to be satisfied with this." [12 ,P.10]

This functional scheme becomes the main functional because the core of the story seems to be the strongest desire of one of the characters in the story.

It can demonstrate as follows:

Initial situation: The Beast tries to approach Beauty to help him break the curse.

Qualifying test of transformation: The Beast invited Beauty to take dinner together every night. Main test of transformation: Three months passed, the Beast purpose Beauty to marry him. Glorifying test of transformation: Beauty always rejected the Beast's proposal.

Final situation: Beast asks her to never leave him even though he has a terrible face for his lifetime.

\section{CONCLUSION}

The discussion of this paper shows the following results. After analyzing the actant and functional structure in Beauty and The Beast, there are 8 actants schema and functional structure that develop these stories. There are 4 actants which are not perfect, in actants 1 , actant 2 , actant 7 and actant 8 because it does not have all the required actant components. From 8 actants, the Beast has a more dominant role as sender than an object meanwhile Beauty and the Merchant has a role as a subject more than the Beast.

Based on the results of the relationship between actants and functional structure, it can be found an actant that becomes the main structure of the stories, is the Beast looking for his true love to break the curse. He uses Beauty to fulfill his desire. But, his 
wishes are blocked by his terrible face, which makes an opponent to his desire.

\section{REFERENCES}

[1] A. Jolles. Simple Forms: Legend, Saga, Myth, Riddle, Saying, Case, Memorabile, Fairytale, Joke. Verso. 2017

[2] K. Sikharulidze. Fairy-Tale as a Genre. Journal of Education (pp. 1-3). doi: 1(2):91-94,2012. ISSN:2298-0245

[3] A.J Greimas, Structural Semantics: An Attempt at a Method. Lincoln and London: University of Nebraska Press. 1966 pp. 146-151

[4] J. Piaget, Structuralism. Jakarta: Yayasan Obor Indonesia. 1995

[5] O. KS Zaimar, A Djokosuyatno. Laporan Penelitian Struktur Cerita Sunda, Aktan dan Fungsinya. (UI Depok, 1992), p.4

[6] G. Januarsyah. Skripsi: Penerapan Model Aktansial Greimas Dalam Cerita Rakyat Roro Jonggrang: Satu Kajian Semiotik Naratif. Bandung: Universitas Padjajaran. 2015

[7] T. Eagleton, Literary Theory An Introduction Second Edition. Blackwell Publisher. 2005

[8] S. Endraswara. Metodologi Penelitian Sastra. FBS Universitas Negeri Yogyakarta. 2004

[9] Jabrohim. PASAR : Dalam Perspektif Greimas. Yogyakarta : Pustaka Pelajar. 1996

[10] E. Resita dan S. Oemiati. Analisis Struktural Dalam Cerpen Hana Karya Akutagawa Ryounosuke. Program Bahasa Jepang. Fakultas Bahasa. Univeritas Dian Nuswantoro. 2014 Access on : Desember 2019

[11] S. Rukoyah. A Thesis : The Actantial and Functional Structure Analysis Of Into The Woods Musical Play. English Letters Department. Faculty of Adab And Humanities. UIN Syarif Hidayatullah Jakarta. 2015

[12] Marie Leprince de Beaumont, Jeanne. 1756. Beauty and The Beast. Global Grey ebooks 